\title{
Purification and Characterization of Polyphenol Oxidase from Edible Yam (Dioscorea
} opposita Thunb.)

\author{
Shuji Fujita ${ }^{1 *}$, Yun-Zhe Han ${ }^{1,2}$, Chie Kouno ${ }^{1}$, Tomoko Matsuo ${ }^{1}$, Megumi Yamashita ${ }^{1}$, \\ Yasuko HARAGUCHI ${ }^{1}$, Ying-Jie LI' ${ }^{1}$, Nobuyuki HAYASHI ${ }^{1}$ and Chang-Peng YANG ${ }^{3}$ \\ ${ }^{1}$ Laboratory of Food Science, Department of Applied Biological Sciences, Faculty of Agriculture, Saga University, Saga 840-8502, \\ Japan \\ ${ }^{2}$ United Graduate School of Agricultural Sciences, Kagoshima University, Kagoshima 890-0065, Japan \\ ${ }^{3}$ Guangxi Agricultural Vocation-Technical College, Nanning 530007, Guangxi, China
}

Received September 14, 2005; Accepted June 21, 2006

\begin{abstract}
Soluble polyphenol oxidase of edible yam (Dioscorea opposita Thunb.) was purified approximately 203fold with a recovery rate of $15 \%$ by ammonium sulfate fractionation, ion exchange chromatography, hydrophobic chromatography and gel filtration using dopamine as a substrate. The purified enzyme appeared as a single band on native PAGE and SDS-PAGE. The molecular weight of the enzyme was estimated to be approximately $42 \mathrm{kDa}$ and $44 \mathrm{kDa}$ using gel filtration and SDS-PAGE, respectively. The purified enzyme quickly oxidized dopamine. The apparent $K_{m}$ value (Michaelis constant) of the enzyme was $1.5 \mathrm{mM}$ for dopamine $\left(\mathrm{pH} 7.0,30^{\circ} \mathrm{C}\right)$. The optimum $\mathrm{pH}$ was 7.0 for dopamine oxidase. In the $\mathrm{pH}$ range from 6 to 10 , the activity was quite stable at $5^{\circ} \mathrm{C}$ for $22 \mathrm{~h}$. The optimum temperature of enzyme activity was $25-30^{\circ} \mathrm{C}$. The activity was stable up to $50^{\circ} \mathrm{C}$ after heat treatment for $20 \mathrm{~min}$. The browning reaction by the enzyme was completely inhibited by $1 \mathrm{mM} \mathrm{L}$-ascorbic acid, which reduced $o$-quinone to dopamine. The reaction was also completely inhibited by $1 \mathrm{mM}$ L-cysteine, which is a known quinone coupler. About $35 \%$ inhibition of edible yam PPO was observed using citric acid and acetic acid at $10 \mathrm{mM}$ in $0.1 \mathrm{M}$ citrate/ $0.2 \mathrm{M}$ sodium phosphate buffer (pH 7). In consideration of the observed results, L-ascorbic acid, L-cysteine, acetic acid, and citric acid are expected to be used as effective inhibitors of enzymatic browning in edible yam.
\end{abstract}

Keywords: polyphenol oxidase, edible yam, dopamine oxidase, purification

\section{Introduction}

Edible yam (Dioscorea opposita Thunb.) is a popular vegetable in Japan. During the processing of this vegetable, undesirable browning occurs in the damaged tissue, primarily due to oxidation of polyphenols by polyphenol oxidase (EC 1.10.3.1; o-diphenol: oxygen oxidoreductase, PPO). Enzymatic browning also occurs in other fruits and vegetables, resulting in lowered marketability. For the prevention of such browning, many investigations have been conducted in order to characterize PPOs in fruits and vegetables (Anosike and Ayaebene, 1981; Ikediobi and Obasuyi, 1982; Tono et al., 1986; Fujita and Tono, 1988; Fujita et al., 1991; Murata et al., 1992; Fujita et al., 1995; Fujita et al., 1997; Ding et al., 1998; Yang et al., 2000; Nkya et al., 2003; Kihara et al., 2005). To characterize the enzyme properties, pyrocatechol, 4-methyl catechol and chlorogenic acid have been widely used as major substrates (Fujita and Tono, 1988; Fujita et al., 1991; Murata et al., 1992; Ding et al., 1998; Nkya et al., 2003; Kihara et al., 2005). Characterization of yam PPO was also performed using catechol as

*To whom correspondence should be addressed.

E-mail : fujitas@cc.saga-u.ac.jp a substrate (Anosike and Ayaebene, 1981; Ikediobi and Obasuyi, 1982; Asemota et al., 1992; Omidigi and Okpuzor, 1996). However, in edible yam and konjak tubes, large quantities of dopamine were detected, which were primarily oxidized by their crude and/or partially purified PPO (Tono, 1970; Tono, 1971; Tono et al., 1974; Tono et al., 1999). These results indicate that enzymatic browning in yam is mainly caused by the oxidation of dopamine by endogeneous PPO (dopamine oxidase); however, little is known about the dopamine oxidase in yam tuber. In our laboratory, we isolated and characterized PPOs, which primarily oxidize dopamine, from banana pulp (Yang et al., 2000). Although the crude PPO from edible yam oxidized dopamine more quickly than other phenols, to date, the characteristics of this enzyme have not been investigated in detail. In the present study, edible yam PPO was purified using dopamine as a substrate, and the properties of the purified enzyme were investigated.

\section{Materials and Method}

Materials Edible yam (D. opposita) was purchased at local markets in Saga city, Japan. DEAE-Toyopearl 650 M, Butyl Toyopearl $650 \mathrm{M}$ and Toyopearl HW 55-Super- 
fine (HW55-S) were obtained from Toso Co., Tokyo. All other reagents used were purchased from Wako Pure Chemical Co., Osaka, and Katayama Chemical Co., Osaka, Japan.

Assay of enzyme activity PPO activity was measured using a colorimetric method (Fujita and Tono, 1988; Fujita et al., 1991; Yang et al., 2000) in a reaction mixture containing $0.5 \mathrm{~mL}$ of $10 \mathrm{mM}$ aqueous solution of various phenols (see Table 2), $4 \mathrm{~mL}$ of $0.1 \mathrm{M}$ citrate/ $0.2 \mathrm{M}$ sodium phosphate buffer (McIlvaine buffer, $\mathrm{pH} 7$ ) and $0.5 \mathrm{~mL}$ of enzyme solution. After $5 \mathrm{~min}$ incubation of the mixture at $30^{\circ} \mathrm{C}$, the increase in absorbance at $420 \mathrm{~nm}\left(\Delta \mathrm{A}_{420}\right)$ was measured using a Shimadzu MPS-2000 spectrophotometer. One unit of enzyme activity was defined as an increase of absorbance of 0.1 per minute and per milliliter of enzyme solution (1 cm light path) at $420 \mathrm{~nm}$.

Protein determination Protein was determined according to the method of Hartree (1972) using a bovine serum albumin (Fraction V, Katayama Chemical Co., Osaka) as a standard. In the chromatography separations, protein was determined by measuring the absorbance at $280 \mathrm{~nm}$.

Enzyme purification All purification steps were carried out at $5{ }^{\circ} \mathrm{C}$. Edible yam tubers (fresh weight $1.7 \mathrm{~kg}$ ) were homogenized with $1000 \mathrm{~mL}$ of $0.1 \mathrm{M}$ potassium phosphate/ $0.1 \mathrm{M}$ sodium phosphate buffer $(0.1 \mathrm{M}$ phosphate buffer, $\mathrm{PB}, \mathrm{pH} 7)$ containing $5 \% n$-hexadecylpyridinium chloride and $0.5 \%$ L-ascorbic acid. After filtration of the homogenate through cotton cloth, the filtrate was centrifuged at $10300 \times \mathrm{g}$ for $20 \mathrm{~min}$, and the supernatant was brought to $80 \%$ ammonium sulfate saturation. After stirring overnight, the protein precipitate was collected by centrifugation at $10300 \times \mathrm{g}$ for $20 \mathrm{~min}$, dissolved in a small volume of $0.01 \mathrm{M} \mathrm{PB}$ ( $\mathrm{pH} 7$ ), and then dialyzed against the same buffer for $36 \mathrm{~h}$ during which the dialyzed media was changed four times. The dialyzed solution (crude enzyme) was applied to a DEAE-Toyopearl column $(3.2 \times 14.5 \mathrm{~cm})$ equilibrated with $0.01 \mathrm{M} \mathrm{PB}(\mathrm{pH} 7)$ and the enzyme fractions, which were not adsorbed on the column, were collected. The enzyme fractions containing $2.0 \mathrm{M}$ ammonium sulfate were applied to a Butyl-Toyopearl column $(1.6 \times 26 \mathrm{~cm})$, equilibrated with $0.01 \mathrm{M}$ PB containing $2.0 \mathrm{M}$ ammonium sulfate, and eluted with a linear gradient of ammonium sulfate (2.0 $\mathrm{M}$ to $0 \mathrm{M}$ in $0.01 \mathrm{M} \mathrm{PB}, \mathrm{pH} 7)$. The enzyme active fractions were pooled and dialyzed against $0.01 \mathrm{M}$ phosphate buffer ( $\mathrm{pH}$ 7) with the dialyzed media changed four times. The dialyzed enzyme solution was applied to a Toyopearl HW 55-S $(1.6 \times 89 \mathrm{~cm})$ column equilibrated with $0.1 \mathrm{M}$ phosphate buffer (pH 7) and eluted with the same buffer. The PPO active fractions were pooled and used for enzyme characterization.

Polyacrylamide gel electrophoresis ( $P A G E$ ) Electrophoresis of the purified enzyme was carried out according to the method of Davis (1964), using 7.5\% polyacrylamide gel at $\mathrm{pH} 9.0$.

Molecularweight determination The molecular weight of the purified enzyme was estimated by gel filtration and SDS-PAGE. Gel filtration was conducted using a Toyopearl HW 55-S column $(1.6 \times 89.0 \mathrm{~cm})$, which was equilibrated and eluted with $0.1 \mathrm{M}$ phosphate buffer $(\mathrm{pH} 7)$, according to the method of Andrews (1965). Chymotrypsinogen A (25 kDa), egg albumin ( $45 \mathrm{kDa})$, bovine serum albumin $(65 \mathrm{kDa})$, and $\gamma$-globulin $(150 \mathrm{kDa})$ were used as marker proteins at a flow rate of $20 \mathrm{~mL}$ per hour.

SDS-PAGE was carried out according to the method described by Laemmli (1970), using SDS-marker protein kit (Bio Rad Co., Helcules CA, USA).

\section{Results and Discussion}

Enzyme purification In this experiment, the mucous polysaccharide in the edible yam extract was initially removed by the addition of $n$-hexadecylpyridinium chloride (Araki et al., 1995), because the polysaccharide interfered with the cotton cloth filtration and anion exchange chromatography in the purification procedures. The enzyme was purified from the homogenates of edible yam by ammonium sulfate fractionation, and chromatography on DEAE-Toyopearl 650M, Butyl Toyopearl $650 \mathrm{M}$, and Toyopearl HW 55-S gel filtration. The purified enzyme showed a single band on native PAGE and SDS-PAGE (Fig. 1). These results suggest that edible yam PPO was purified to a homogeneous state. The typical result for the stepwise purification of the enzyme is given in Table 1. Finally, the enzyme was purified approximately 203fold with a recovery rate of $15 \%$ when compared with the crude extract.

Some properties of edible yam PPO As shown in Fig. 2 , the molecular weight of the native enzyme was estimated to be approximately $42 \mathrm{kDa}$ by gel filtration, and a subunit molecular weight of $44 \mathrm{kDa}$ by SDS-PAGE. These results may indicate that the purified PPO is a monomer. The molecular weight of the purified enzyme was much smaller than that of white yam (D. rotundata) PPO (MW $107 \mathrm{kDa}$ ), which quickly oxidized catechol (Ikediobi and Obasuyi, 1982). However, the molecular weight of our
(A)

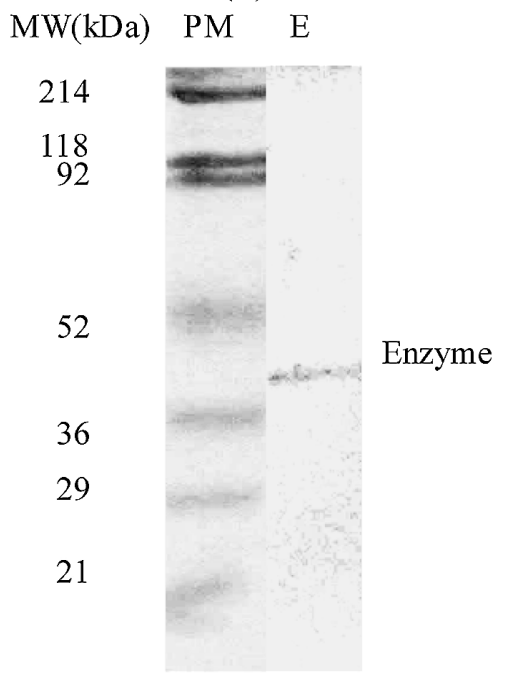

(B)

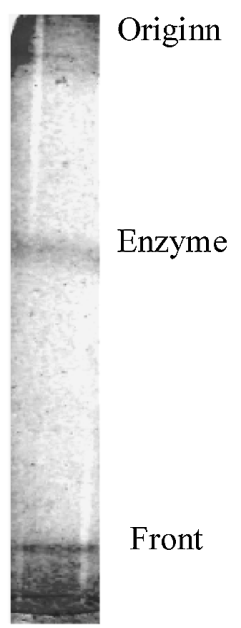

Fig. 1. SDS-PAGE (A) and PAGE (B) of the purified PPO of edible yam.

(A); PM, protein marker; E, purified enzyme; MW, molecular weight.

(B), Enzyme, purified enzyme. 
Table 1. Purification summary of polyphenol oxidase of edible yam.

\begin{tabular}{lccccc}
\hline Procedure & $\begin{array}{c}\text { Total protein } \\
(\mathrm{mg})\end{array}$ & $\begin{array}{c}\text { Total } \\
\text { activity (KU) }\end{array}$ & $\begin{array}{c}\text { Specific } \\
\text { activity (units/mg) }\end{array}$ & $\begin{array}{c}\text { Purification } \\
\text { (fold) }\end{array}$ & $\begin{array}{c}\text { Recovery } \\
(\%)\end{array}$ \\
\hline Crude extract & 13603 & 205 & 15.1 & 1.0 & 100.0 \\
$80 \%\left(\mathrm{NH}_{4}\right)_{2} \mathrm{SO}_{4}$ saturation & 1118 & 74 & 66.6 & 4.4 & 36.1 \\
DEAE-Toyopearl 650M & 1125 & 56 & 50.0 & 3.3 & 27.3 \\
Butyl-Toyopearl 650M & 26.3 & 39 & 1480 & 98.0 & 19.0 \\
Toyopearl HW-55S & 9.8 & 30 & 3068 & 203.0 & 14.6 \\
\hline
\end{tabular}

Each value is the mean of three trials.
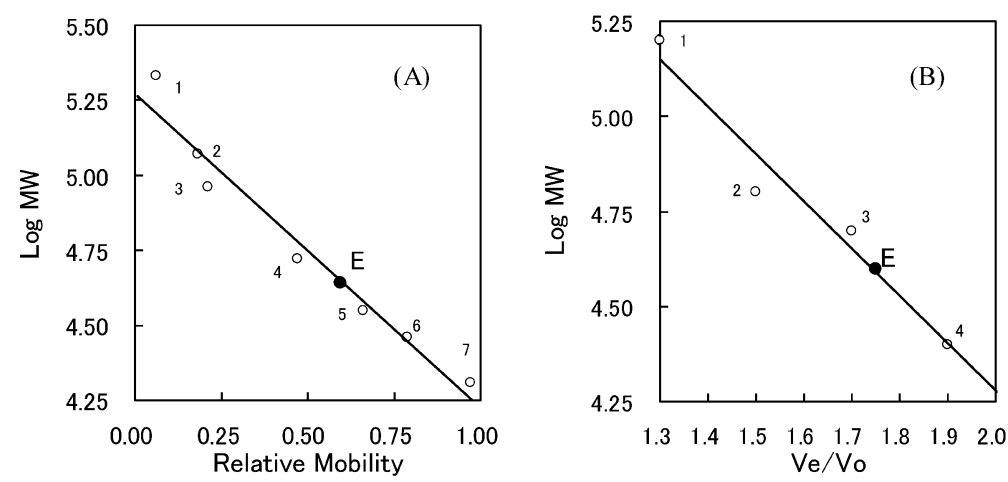

Fig. 2. Estimation of molecular weight (MW) of purified PPO of edible yam by gel filtration on SDS-PAGE (A) and Toyopearl HW $55 \mathrm{~S}(\mathrm{~B})$.

(A): 1 , myosin (214 kDa); 2, $\beta$-galactosidase (118 kDa); 3, bovine serum albumin $(92 \mathrm{kDa})$; 4, ovalbumin $(52.2 \mathrm{kDa}) ; 5$, carbonic anhydrase $(35.7 \mathrm{kDa})$; 6 , soy bean trypsin inhibitor $(28.9 \mathrm{kDa})$; 7 , lysozyme $(20.8 \mathrm{kDa})$; E, purified enzyme. (B): Vo, void volume of the column; Ve, elution volume of the substance; $1, \gamma$-globulin (150 kDa); 2 , bovine serum albumin $(65 \mathrm{kDa})$; 3, egg albumin $(45 \mathrm{kDa})$; 4, chymotrypsinogen A $(25 \mathrm{kDa})$; E, purified enzyme.

Table 2. Substrate specificity of edible yam PPO.

\begin{tabular}{lc}
\hline Substrate & Relative activity (\%) \\
\hline Dopamine & 100 \\
Catechol & 35 \\
Epicatechin & 20 \\
Chlorogenic acid & 6.5 \\
DL-Dopa & 6.5 \\
Pyrogallol & 15 \\
Gallic acid & 0 \\
Phloroglucinol & 0 \\
Resorcinol & 0 \\
\hline
\end{tabular}

Reactions were carried out in Mcillvaine buffer $(\mathrm{pH} 7)$ at $30^{\circ} \mathrm{C}$. Each value is the mean of three trials.

D. opposita purified PPO was similar to that of the banana pulp dopamine oxidase (Yang et al., 2000), which has an estimated molecular weight of approximately $41 \mathrm{kDa}$ and $42 \mathrm{kDa}$ by gel filtration and SDS-PAGE, respectively. The molecular weight of D. opposita PPO was smaller than that of the PPO of Japanese pears (MW $56 \mathrm{kDa}$ ) (Tono et al., 1986), head lettuce (MW $56 \mathrm{kDa}$ ) (Fujita et al., 1991), and apple (MW $65 \mathrm{kDa}$ ) (Murata et al., 1992), which quickly oxidized chlorogenic acid.

Table 2 shows substrate specificity of the purified enzyme. The purified enzyme quickly oxidized dopamine. The oxidation rate for pyrocatechol and epicatechin by the PPO was low compared to that of dopamine. The enzyme had very weak or no activity towards such tri- 
hydroxybenzenes as phloroglucinol and gallic acid. In contrast, purified white yam (D. routundata) PPO quickly oxidized catechol and chlorogenic acid (Ikediobi and Obasuyi, 1982). The different substrate specificity between $D$. opposita and $D$. rotundata may due to the difference in the species and/or cultivar of yam. Similar substrate specificity of $D$. opposita PPO was observed for the banana pulp PPO (Yang et al., 2000). Such substrate specificity of PPOs in D. opposita and banana also differs from the PPO of Japanese pear (Tono et al., 1986), eggplant (Fujita and Tono, 1988), lettuce (Fujita et al., 1991), apple (Murata et al., 1992), and garland chrysanthemum (Nka et al., 2003), which quickly oxidized chlorogenic acid. In edible yam, dopamine was detected in large quantities (Tono, 1970; Tono, 1971; Tono et al., 1999). These results suggest that enzymatic browning in yam is primarily caused by the oxidation of dopamine by PPO. Therefore, the purified $D$. opposita PPO can be considered a dopamine oxidase. The $K_{m}$ value of the enzyme was $1.5 \mathrm{mM}$, measured from Lineweaver-Burk plots using dopamine as a substrate $\left(\mathrm{pH} 7.0,30^{\circ} \mathrm{C}\right)$. This value is similar to that of banana pulp dopamine oxidase (Yang et al., 2000), which has a value of $2.8 \mathrm{mM}$.

Other properties of the purified enzyme are listed in Table 3. The purified PPO showed a single but broad $\mathrm{pH}$ optimum curve between $\mathrm{pH} 6$ to 8 with maximum activity at pH 7. This value is similar to the optimum pH of PPOs in kiwi fruit (Park and Luh, 1985), guava (Augustin et al., 1985), banana pulp (Yang et al., 2000), and another species of yam tuber (Anosike and Ayaebene, 1981; Ikediobi and Obasuyi, 1982). However, it differed from PPOs of eggplant (Fujita and Tono 1988), apple (Murata et al., 1992), and garland chrysanthemum (Nkya et al., 2003), which have an optimum $\mathrm{pH}$ of 4 . More than $80 \%$ of the original activity remained after incubation for $48 \mathrm{~h}$ between $\mathrm{pH} 4$ and 10. The pH stability differed slightly from the PPOs of Japanese pear (Tono et al. 1986), eggplant (Fujita and Tono, 1988), lettuce (Fujita et al., 1991), apple (Murata et al., 1992), banana pulp (Yang et al., 2000), and garland chrysanthemum (Nkya et al., 2003), for which, more than $90 \%$ of the PPOs' original activity remained after incubation for $48 \mathrm{n}$ between $\mathrm{pH} 4$ and 10 .

The purified PPO showed a single but broad optimum temperature curve from 20 to $30^{\circ} \mathrm{C}$ with maximum activity at $30^{\circ} \mathrm{C}$. This value is similar to the optimum temperature of the PPO of another species of yam tuber (Ikediobi and Obasuyi, 1982; Omidiji and Okpuzor, 1996). The PPO activity remained unchanged after heat treatment at $50^{\circ} \mathrm{C}$ for $30 \mathrm{~min}$. These results indicated that the enzyme has relatively high thermal stability. Similar thermal stability has also been reported for the PPOs of another species of yam (Ikediobi and Obasuyi, 1982), kiwi fruit (Park amd Luh, 1985), lettuce (Fujita et al., 1991), cabbage (Fujita et al., 1995), banana pulp (Yang et al., 2000), and garland

Table 3. Some properties of edible yam PPO.

\begin{tabular}{|c|c|c|}
\hline 1. Optimum $\mathrm{pH}^{1)}$ & \multicolumn{2}{|c|}{7} \\
\hline 2. $\mathrm{pH}_{\text {stability }}{ }^{2)}$ & \multicolumn{2}{|c|}{$4-10$} \\
\hline 3. Optimum temperature ${ }^{3)}$ & \multicolumn{2}{|c|}{$30{ }^{\circ} \mathrm{C}$} \\
\hline 4. Thermal stability ${ }^{4)}$ & \multicolumn{2}{|c|}{$50{ }^{\circ} \mathrm{C}$} \\
\hline \multicolumn{3}{|l|}{ 5. Effectors ${ }^{5)}$} \\
\hline \multirow{2}{*}{ Compounds } & \multicolumn{2}{|c|}{ Relative activity (\%) } \\
\hline & $1 \mathrm{mM}^{\mathrm{a}}$ & $10 \mathrm{mM}^{\mathrm{a}}$ \\
\hline None & 100.0 & 100.0 \\
\hline Sodium diethyldithiocarbamate & 0.0 & 0.0 \\
\hline EDTA & 91.5 & 76.9 \\
\hline $\mathrm{KCN}$ & 1.7 & 0.5 \\
\hline $\mathrm{NaF}$ & 95.7 & 77.5 \\
\hline $\mathrm{NaCl}$ & 95.7 & 85.5 \\
\hline $\mathrm{BaCl}_{2}$ & 87.5 & - \\
\hline $\mathrm{ZnSO}_{4}$ & 93.9 & - \\
\hline L-Ascorbic acid & 0.0 & 0.0 \\
\hline L-Cysteine & 0.0 & 0.0 \\
\hline Citric acid & 88.4 & 63.0 \\
\hline Acetic acid & 85.5 & 66.7 \\
\hline
\end{tabular}

1) Reactions were carried out at different $\mathrm{pH}$ levels at $30^{\circ} \mathrm{C}$.

2) Reactions were carried out in Mcillvaine buffer $(\mathrm{pH} 7.0)$ at $30^{\circ} \mathrm{C}$.

3) Reactions were carried out in Mcillvaine buffer ( $\mathrm{pH} 7.0$ ).

4) Reactions were carried out in Mcillvaine buffer $\left(\mathrm{pH} \mathrm{7.0)}\right.$ at $30^{\circ} \mathrm{C}$.

5) The reactions were carried out in Mcillvaine buffer $(\mathrm{pH} 7.0)$ at $30^{\circ} \mathrm{C}$. Each value is

the mean of three trials. ${ }^{a}$; Final concentration of various compounds -; not determined

(solutions were cloudy). 
chrysanthemum (Nkya et al., 2003).

The enzyme activity was almost completely inhibited by sodium diethyldithiocarbamate and potassium cyanide at $1 \mathrm{mM}$. Only $5-13 \%$ inhibition of the enzyme reactions was observed following the addition of metal ions $\left(\mathrm{Ba}^{2+}\right.$, $\mathrm{Zn}^{2+}$ ), EDTA, and sodium fluoride at $1 \mathrm{mM}$. The browning reaction of the enzyme was completely inhibited by $1 \mathrm{mM}$ L-ascorbic acid, which reduced $o$-quinone to dopamine. The reaction was also completely inhibited by $1 \mathrm{mM} \mathrm{L}$ cysteine, which is a known quinone coupler. Similar effects of these compounds have been observed for PPOs of another species of yam (Ikediobi and Obasuyi, 1982), Japanese pear (Tono et al 1986), head lettuce (Fujita et al., 1991), and cabbage (Fujita et al., 1995). For dopamine oxidase in banana pulp (yang et al., 2000), its activity is markedly inhibited by citric acid and acetic acid at $10 \mathrm{mM}$ under relatively low buffer capacities (using 0.01 M PB, pH 7). In contrast, approximately $35 \%$ inhibition of edible yam dopamine oxidase was observed for the use of citric acid and acetic acid at $10 \mathrm{mM}$ with relatively high buffer capacity (using McIlvaine buffer, pH 7). Similar effects of citric acid and acetic acid on edible yam dopamine oxidase have been reported for garland chrysanthemum PPO (Nkya et al., 2003).

In conclusion, PPO of edible yam (D. opposita) was purified to approximately 203 -fold with a recovery rate of $15 \%$, using dopamine as a substrate. The molecular weight and substrate specificities of the purified PPO (dopamine oxidase) differed from those of white yam (D. rotundata) PPO (catechol oxidase); however, the effect of $\mathrm{pH}$, temperature, and various compounds on enzyme activity were similar. These findings indicate that the difference in substrate specificity and molecular weight between $D$. opposita and $D$. rotundata was due to the different species and/or cultivar of yam. Because dopamine was detected in large quantities (Tono, 1970; Tono, 1971; Tono et al., 1999) and the PPO quickly oxidized dopamine, the enzymatic browning in yam appears to be primarily due to the oxidation of dopamine by the dopamine oxidase. In consideration of the present results, L-ascorbic acid, L-cysteine, acetic acid, and citric acid are expected to be used as effective inhibitors of enzymatic browning in edible yam.

\section{References}

Andrews, P. (1965). The gel-filtration behavior of proteins related to their molecular weight over wide range. Biochem. J., 96, 595605.

Anosike, E.O., Ayaebene, A.O. (1981). Purification and some properties of polyphenol oxidase from the yam tubers, Dioscorea bulbifera. Phytochem., 20, 2625-2628.

Araki, T., Kuramoto, M. and Torikata, T. (1995). Purification of three acidic chitinases from yam aerial tuber. Application of quaternary ammonium ion detergent for separation of yam chitinase from viscous tissue extract. Biosci, Biotech. Biochem., 59, 430-434.

Asemota, H.N., Wellington M.A., Odutuga A.A. and Ahamad M.H. (1992). Effect of short-term storage on phenolic content, $o$-diphenolase and peroxidase activities of cut yam tubers
(Dioscorea sp). J. Sci. Food Agric., 60, 309-312.

Augustin, M.A., Ghazali, H.M. and Hashim, H. (1985). Polyphenoloxidase from guava (Psidium guajava L). J. Sci. Food Agric., 36, 1259-1265.

Davis, B.J. (1964). Disc gel electrophoresis. 2. Method and application to human serum proteins. Ann. N. Y. Acad. Sci., 121, 404427.

Ding, C. K.; Chachin, K., Ueda, Y., Imahori, Y. (1998). Purification and properties of polyphenol oxidase from loquat fruit. $J$. Agric. Food Chem., 46, 4144-4149.

Fujita, S. and Tono, T. (1988). Purification and some properties of polyphenol oxidase in eggplant (Solanum melongena). J. Sci. Food Agric., 46, 115-123.

Fujita, S., Tono, T. and Kawahara, H. (1991). Purification and properties of polyphenol oxidase in head lettuce (Lactuca sativa). J. Sci. Food Agric., 55, 643-651.

Fujita, S., Saari, N., Maegawa, M., Tetsuka, T., Hayashi, N. and Tono, T. (1995). Purification and properties of polyphenol oxidase from cabbage (Brassica oleracea L.). J. Agric. Food Chem., 43, 1138-1142.

Hartree, E.F. (1972). Determination of protein: a modification of Lowry method that gives a linear photometric response. Anal. Biochem., 48, 422-427.

Ikediobi, C.O. and Obasuyi H.N. (1982). Purification and some properties of o-diphenolase from white yam tubers. Phytochemistry, 21, 2815-2820.

Kihara, T., Murata, M., Homma, S., Kaneko, S. and Komae, K. (2005). Purification and characterization of Wheat (Triticum aestivum) polyphenol oxidase. Food Sci. Technol. Res., 11, 87-94.

Laemmli, U.K. (1970). Cleavage of structural proteins during the assembly of the head bacteriophage T4. Nature, 227, 680-685.

Murata, M., Kurokami, C. and Homma, S. (1992). Purification and some properties of chlorogenic acid oxidase from apple (Malus pumula). Biosci. Biotech. Biochem., 56, 1705-1710.

Nkya, E., Kouno, C., Li, Y.-J., Yang, C.-P., Hayashi, N. and Fujita, S. (2003). Purification and characterization of polyphenol oxidase from garland chrysanthemum (Chrysanthemum coronarium L.). J. Agric. Food Chem., 51, 5467-5471.

Omidiji, O. and Okpuzor, J. (1996). Time course of PPO-related Browning of yams. J. Sci. Food Agric., 70, 190-196.

Park, E.Y. and Luh, B.S. (1985). Polyphenol oxidase of kiwi fruit. J. Food Sci., 50, 679-684.

Tono, T. (1970). Isolation of dopamine and browning of tubers of Chinese yam (Dioscorea batatas). Nippon shokuhin Kogyou Gakkaishi, 17, 447-450 (in Japanese).

Tono, T. (1971). A tetrahydroisoquinoline derivative isolated from the acetone extract of Dioscorea batatas. Agric. Biol. Chem., 35, 619-621.

Tono, T.; Fujita, S. and Ito, T. (1974). Identification of dopamine in the tubers of konjak (Amorphophallus konjak). Eiyo to Shokuryo, 27, 467-470 (in Japanese).

Tono, T., Fujita, S., Kawasaki, H. and Li, Z.F. (1986). Purification and high L-epicatechin oxidase activity in polyphenol oxidase of Japanese pear. Nippon Nogeikagaku Kaishi, 60, 705-712 (in Japanese)

Tono, T., Takedomi, K., Ikeda. T., Oka, C. and Fujita, S. (1999). Difference spectrophotometric analysis of catecholamine using polyphenol oxidase from edible yam (Dioscorea). J. Nishikyushu Univ. \& Saga Junior College. 29, 1-5.

Yang, C.-P., Fujita, S., Ashrafuzzaman, Md., Nakamura, N. and Hayashi, N. (2000). Purification and characterization of polyphenol oxidase from banana (Musa sapientum L.) pulp. J. Agric. Food Chem., 48, 2732-2735. 